\title{
Szczepan Wojdyła
}

\author{
Uniwersytet Opolski
}

\section{Obietnice wyborcze a etyka - co można obiecać a co zrealizować? Wybrane obietnice wyborcze polskich partii politycznych.}

Gdy mówimy o kampaniach wyborczych nie sposób nie poruszyć kwestii etyki. Choć samo wyrażenie „etyka” oznacza dział filozofii, zajmujący się badaniem źródeł moralności człowieka, to w kontekście wyborów można je sprowadzić do uczciwości i tzw. przejrzystości, transparentności. Będziemy ją tutaj rozumieć jako szeroko pojętą uczciwość, zgodność ze standardami (ale nie tymi, które obecnie samodzielnie się wykształciły, a raczej z tymi pierwotnymi, dającymi się określić jako swoiste wzorce moralne). Etykę, czy może raczej etyczność danego działania, można po części utożsamić z merytorycznościa, uczciwością, szczerością i prawością.

Dochodzimy tu także do pojęcia manipulacji. Bardzo często obietnice wyborcze składane są nie dlatego, że taki jest program danej partii, lecz tylko z powodów czysto pragmatycznych - dla zdobycia poparcia wyborców, bez intencji realizacji w razie zwycięstwa wyborczego'.

Współczesna nauka rozróżnia 3 rodzaje kampanii wyborczych - premodernizacyjne, modernizacyjne i postmodernizacyjne22. W naszym kraju, podobnie jak w innych rozwiniętych krajach, mamy do czynienia z kampanią postmodernizacyjna, która w moim uznaniu, już przez sam swój charakter może być uznana za etycznie wątpliwą. Dzieje się tak dlatego, że zgodnie z jej definicją trwa ona permanentnie, od wyborów do wyborów, podczas gdy zgodnie z polskim prawem, kampania wy-

\footnotetext{
1 P. Zynk, Od komunikacji do manipulacji, Europsky institut skumania medzinarodnych vzt'ahov, s.r.o., Kezmarok 2008, s. 75.

2 B. Dobek-Ostrowska (red.), Kampania wyborcza: marketingowe aspekty komunikowania politycznego, Wrocław 2005, s. 18-23.
} 
borcza odbywać powinna się tylko w ściśle wyznaczonych ramach czasowych (od chwili ogłoszenia daty wyborów do dnia ciszy wyborczej) $)^{3}$.

Skoro już omówiliśmy etykę, czas wyjaśnić czym są obietnice wyborcze. Według wyroku sądu, wydanego przez Aleksandrę Różalską-Daniluczuk, w procesie przeciwko Platformie Obywatelskiej, "przedwyborczej obietnicy partii nie można traktować jako umowy albo przyrzeczenia publicznego"4. W związku z tym wyrokiem sądu (jak również wcześniejszymi, podobnymi wyrokami m.in. W procesie przeciwko Lechowi Wałęsie) możemy uznać, że obietnice wyborcze zdefiniować można jako niezobowiazzujące deklaracje, mające na celu przedstawienie programu partii (lub kandydata) oraz zdobycie poparcia wyborczego.

Co w takim razie obiecuja partie swoim potencjalnym wyborcom? Postaram się prześledzić kilkanaście obietnic, złożonych przez różne ugrupowania w kilku kolejnych kampaniach oraz ocenić, czy obietnice te były możliwymi do zrealizowania postulatami programowymi, czy też może tylko hasłami propagandowymi bez pokrycia w woli i możliwościach.

Na początek przyjrzę się obietnicom, jakie zostały złożone podczas kampanii prezydenckiej w 2010 roku przez Bronisława Komorowskiego i Jarosława Kaczyńskiego. Celowo nie skupiam się na tym, kto składał jakie obietnice, bowiem moim celem nie jest rozliczenie poszczególnych kandydatów, lecz wskazanie, jakie obietnice należy traktować $z$ daleko posunięta ostrożnością.

Pierwszą z obietnic, jakie padły w tej kampanii, a którym pragnę się przyjrzeć, jest hasło utrzymania tzw. KRUS-u. Jest to instytucja powołana na mocy ustawy z 1990 roku, odpowiedzialna za ubezpieczenia społeczne rolników5. Jak więc widać, jest to hasło właściwe dla kampanii wyborczej do parlamentu, jednak zupełnie nie przystające do wyborów prezydenckich. Jest tak przede wszystkim dlatego, że prezydent w polskim systemie politycznym jest przede wszystkim organem władzy wykonawczej, a jego udział w ustawodawstwie, ogranicza się do inicjatywy ustawodawczej. Niemożliwa jest więc prosta zależność, w której elekcja danego kandydata oznacza utrzymanie lub zlikwidowanie KRUS, co wydaje się sugerować złożona w ten sposób obietnica.

3 W. Cwalina, A. Falkowski, Marketing polityczny. Perspektywa psychologiczna, Gdańsk 2005, s. 551552.

4 Sąd: nie będzie odszkodowania za niezrealizowane obietnice wyborcze $P O$, www.polskieradio.pl/5/3/Artykul/320724,Sad-nie-bedzie-odszkodowania-za-niezrealizowane-obietnicewyborcze-PO, data dostępu 18.02.2013.

5 Dz. U. z 2008 r. Nr 50, poz. 291. 
Podobny mechanizm dotyczy kolejnej obietnicy, brzmiacej bardzo ogólnie - „pieniądze dla rolników”. W tym wypadku, oprócz poruszonej wcześniej kwestii nieadekwatności pozycji prezydenta do takich działań, spotykamy się z bardzo wysokim poziomem ogólności złożonej obietnicy, wskutek czego wyborcy bardzo łatwo mogą zostać wprowadzeni w błąd lub celowo zmanipulowani. Jeśli dodamy do tego marginalną rolę prezydenta w tworzeniu budżetu, otrzymujemy sytuację, gdzie złożenie tak brzmiącej obietnicy okazuje się niczym innym jak próbą „wyłudzenia" głosów lub prezentacja programu, lecz nie kandydata, a popierajacej go partii, co w naszych warunkach zdarza się bardzo często.

Obietnica, która budzi moje głębokie watpliwości jest również zapowiedź utworzenia „Muzeum Ziem Zachodnich”. Ważny jest jednak kontekst, w jakim została złożona, bowiem w tym wypadku słowa brzmiały: „Musimy powołać Muzeum Ziem Zachodnich" i padły z ust Jarosława Kaczyńskiego, podczas wystapienia we Wrocławiú. Czy wobec tego możemy mówić w ogóle o obietnicy? Uważam, że tak, bowiem słowa te nie zostały wypowiedziane przypadkowo. Skoro bowiem kandydat na prezydenta mówi, że coś musi zostać zrobione to w rozumieniu jego wyborców, w momencie elekcji podejmie on kroki by to zrealizować. Tymczasem taka wypowiedź nie zawiera deklaracji takiego postępowania, nie zawiera również deklarowanego czasu realizacji. Powstaje więc figura retoryczna, która w oczach wyborców wydaje się być obietnica, choć z punktu widzenia osoby, która te słowa wypowiada, wcale nią nie jest. Pozostaje jednak kwestia intencji. Czy autor wypowiedzi chciał dać wyborcom do zrozumienia, że zamierza podjać jakieś działania? A może tylko zwrócić ich uwage na potrzeby danego miasta? Na to pytanie nie poznamy odpowiedzi. Biorąc jednak pod uwagę realia kampanii wyborczej, przychylać się można do tego pierwszego wytłumaczenia.

O ile w przypadku wyborów prezydenckich można mówić, że obietnice składane są przez samych kandydatów i można by myśleć o pociagnięciu ich za nie do odpowiedzialności (oczywiście mając na uwadze przywoływane wcześniej wyroki sadowe), to w przypadku wyborów parlamentarnych, odpowiedzialność za obietnice, a także za program wyborczy nie powinna być kwestią tylko lidera partii, lecz ugrupowania jako całości.

Moje rozważania rozpocznę od Prawa i Sprawiedliwości i jednej z najsłynniejszych obietnic wyborczych w III RP - 3 mln mieszkań, a dokładniej 3 do 4 milio-

${ }^{6}$ Muzeum Ziem Zachodnich. Nowa obietnica Kaczyńskiego, www.polska.newsweek.pl/muzeum-ziemzachodnich--nowa-obietnica-kaczynskiego,61217,1,1.html, data dostępu 27.02.2013. 
nów, bo o takiej liczbie mieszkań (wybudowanych w ciagu 8 lat) wspomina program wyborczy PiS z 2005 roku. Obietnica ta, na pierwszy rzut oka wydaje się bardzo konkretna - zdiagnozowana zostaje potrzeba społeczna, przedstawione jest rozwiazanie i wyznaczona granica czasowa. Problem pojawia się w momencie, gdy zaczynamy myśleć o realizacji tego pomysłu. Wymaga to podjęcia odpowiednich uchwał przez parlament. Prowadzi to do sytuacji, którą obserwujemy dziś w odniesieniu do autostrad. Państwo może podjąć działania zmierzające ku rozbudowie infrastruktury (lub jak w przypadku tej obietnicy zasobów mieszkaniowych), jednak żadna partia, ani rząd nie powinny formułować takich obietnic, m.in. ze względu na procedury przetargowe, wykupy gruntów itd. Przyznać należy, że spośród rozpatrywanych tu deklaracji wyborczych, tę obietnicę można uznać za jedną z bardziej etycznych, bowiem można myśleć o jej realizacji.

Następną z „dużych” czy może raczej „głośnych” obietnic PiS, również z 2005 roku, było hasło likwidacji NFZ8. W tej obietnicy nie ma nic nierealnego ani niemożliwego do zrealizowania. Likwidacja tej instytucji, podobnie jak poprzednio jej powołanie leży całkowicie w kompetencjach parlamentu i rządu. Problem w tym, że pomimo stworzenia koalicji rządowej, PiS nie podjał się realizacji tej obietnicy, co więcej, powracał do niej w kolejnych programach wyborczych. Dlaczego więc nie zrealizował jej wtedy, gdy był u władzy? Odpowiedź może być dwojaka. Albo uniemożliwiła to umowa koalicyjna (koalicja PiS, Samoobrona, Liga Polskich Rodzin), albo nie było faktycznej woli do zrealizowania tej obietnicy. Ponieważ programy koalicjantów skłaniały się również ku likwidacji tej instytucji, należy stwierdzić, że jednak zabrakło woli, lub czasu, ponieważ trzeba pamiętać, że mówimy o skróconej kadencji sejmu. Tym niemniej, należy stwierdzić, że wyborcy mieli prawo czuć się oszukani z powodu braku zrealizowania obietnicy, dotyczącej tak ważnego obszaru jakim jest służba zdrowia.

Ciekawy jest także temat obietnicy związanej z budową dróg. Postulat ten spotkać możemy w programie niemal każdej partii. W programie Prawa i Sprawiedliwości z 2007 roku znajduje on jednak bardzo konkretny wymiar - ok. 1000 km autostrad i ok. 2000 km dróg ekspresowych, wybudowanych w latach 2008-2012,

7 Program wyborczy Prawa i Sprawiedliwości 2005, „IV Rzeczpospolita. Sprawiedliwość dla wszystkich", s. 76.

8 Ibidem, s. 87. 
przy współudziale środków unijnych ${ }^{9}$. Założenie szczytne i z pewnością oczekiwane przez wyborców, postawić należy jednak pytanie, czy możliwe do zrealizowania? Teoretycznie tak, w końcu przykład chociażby hitlerowskich Niemiec pokazał, że w ciagu kilku lat da się wybudować tysiące kilometrów dróg. Przy takich szacunkach, należy jednak brać pod uwagę także specyfikę czasu i miejsca. W przypadku Polski, w ciagu 4 lat poprzedzających wybory, a więc od roku 2003 do 2007 powstało zaledwie $200 \mathrm{~km}$ autostrad i $200 \mathrm{~km}$ dróg ekspresowych ${ }^{10}$. Dla porównania, Platforma Obywatelska, która również obiecywała rozbudowę infrastruktury, jednak nie podawała w programie wyborczym żadnych liczb, w czasie rządów w koalicji z Polskim Stronnictwem Ludowym zdołała oddać do użytku do 2012 roku tylko niecałe $500 \mathrm{~km}$ autostrad i ok. $500 \mathrm{~km}$ dróg ekspresowych ${ }^{11} \mathrm{i}$ to pomimo znacznego (jak by się mogło wydawać) przyspieszenia prac w związu z mistrzostwami Europy w piłce nożnej, współorganizowanymi przez Polskę i Ukrainę. Jak widać obietnica, która znajdujemy w programie wyborczym PiS z 2007 roku była niemożliwa do zrealizowania i założyć należy, że osoby odpowiedzialne za przygotowanie programu były świadome niemożności jej realizacji.

W programie wyborczym Platformy Obywatelskiej z 2007 roku pojawia się obietnica zniesienia immunitetu parlamentarnego ${ }^{12}$. Miało by się to odbyć przy zachowaniu zasady nietykalności cielesnej posłów i senatorów. Mimo sprawowania rządów przez pełną kadencję oraz zwycięstwa w kolejnych wyborach, postulat ten nie został zrealizowany. Co więcej, nie podjęto żadnych konkretnych prób jego realizacji, wobec czego można domniemywać, że był to zwykły slogan wyborczy. Tym samym, mamy tu doskonały przykład obietnicy, która została złożona pomimo pełnej świadomości, że nie będzie ona realizowana, co zasługuje na słuszne potępienie jako zachowanie nieetyczne.

Kolejną watpliwą etycznie deklaracją była w moim uznaniu obietnica niskich podatków oraz wprowadzenia podatku liniowego'13. Punkt ten pojawiał się w programie wyborczym Platformy Obywatelskiej już od 2005 roku. Pomimo zwycię-

\footnotetext{
9 I. Słodkowska, M. Dołbakowska (red), Wybory 2007. Partie i ich programy, Warszawa 2011, s. 142143.

10 Historia budowy autostrad i dróg ekspresowych w Polsce, www.stadiony.klszarak.org/scc_a_s.swf, data dostępu 27.02.2013.

11 lbidem.

12 I. Słodkowska, M. Dołbakowska (red), op. cit., s. 204.

13 Platforma Obywatelska - program gospodarczy, www.bankier.pl/wiadomosc/Platforma-ObywatelskaPO-program-gospodarczy-1643620.html, data dostępu 1.03.2013.
} 
stwa w wyborach w 2007 roku, a później w 2011, PO do dziś nie zdecydowała się na wprowadzenie tej obietnicy w życie. Należy tu oczywiście wziąć pod uwagę światowy kryzys gospodarczy, który zmusił wiele rządów do zmiany swoich planów. Jednak ten argument traci nieco na sile, gdy weźmiemy pod uwagę, że początek kryzysu datowany jest na 2008 rok, podczas gdy PO w koalicji z PSL rozpoczęło swoją kadencję jeszcze w 2007 roku. Ponownie pojawia się pytanie, czy partia miała w ogóle zamiar realizować ten punkt swojego programu, czy też może był to jedynie „wabik” na wyborców. Trudno orzekać z cała pewnościa, jednak nie podlega wątpliwością fakt, że sporo głosów PO zawdzięcza właśnie zwolennikom podatku liniowego.

Za bardzo ciekawą można uznać obietnicę złożoną przez Sojusz Lewicy Demokratycznej, w zwycięskich wyborach w 2001 roku. Była to deklaracja pomocy w znalezieniu pracy dla każdego absolwenta studiów wyższych ${ }^{14}$. W sytuacji, gdy rynek pracy w Polsce nigdy nie stwarzał zbyt przyjaznych warunków dla nowych pracowników (zwłaszcza z wykształceniem humanistycznym), taka obietnica z pewnością przełożyła się na pewną ilość głosów młodych wyborców. Problemem jednak ponownie są znacznie ograniczone możliwości realizacji takiej deklaracji. Rząd może wprowadzić reformy zmierzajace do wsparcia rozwoju przedsiębiorczości i stymulować gospodarkę, jednak nie może zagwarantować nikomu miejsc pracy. Pomijam tu celowo sytuacje nieprzewidywalne, jak wspominany powyżej światowy kryzys gospodarczy. Koniecznie należy także wspomnieć o tym, że obietnica ta pomimo zwycięstwa wyborczego SLD i utworzenia koalicji z Unią Pracy i Polskim Stronnictwem Ludowym, nie została zrealizowana, co także dowodzi, że nie było to możliwe, co z kolei prowadzi do stwierdzenia, że obietnica ta została złożona tylko w celu osiagnięcia zwycięstwa wyborczego.

W 2001 roku SLD złożył również w swoim programie obietnicę wprowadzenia regulacji prawnych, dających pełną równość na rynku pracy kobietom i mężczyznom pod względem dostępu do pracy, łatwości awansów oraz wysokości wynagrodzeń ${ }^{15}$. Jednak po 4 latach rządów tej koalicji, a nawet i dziś, 3 kadencje i 2 rządy później, raporty Głównego Urzędu Statystycznego wskazują, że nadal udział kobiet w rynku pracy jest znacząco mniejszy niż mężczyzn, osiagając przy tym

\footnotetext{
14 Program wyborczy koalicji SLD i UP 2001, www.sld.org.pl/public/ckfinder/userfiles/files/Program_ Wyborczy_SLDiUP_2001.txt, data dostępu 1.03.2013.

15 Ibidem.
} 
niższe zarobki ${ }^{16}$. Jest to zatem kolejny przypadek sytuacji, w której złożona obietnica, choć bardzo miła dla wyborców, jest jednak niemożliwa do zrealizowania, przynajmniej nie bezpośrednio i dosłownie. Rząd może podjąć działania zmierzające do realizacji takich postulatów, jednak nie można składać obietnic zapowiadających wprost pewne efekty, zwłaszcza w sytuacji gdy jest to sprawa tak złożona.

Jak zostało wspomniane, obietnice podzielić możemy na te, które składane sa jako element faktycznego programu wyborczego oraz te, które pełnia rolę jedynie „wabika” na wyborców i nie ma albo woli albo możliwości ich realizacji. Większość wyborców nie odróżnia niestety manipulacji od perswazji. Podczas gdy perswazja, to przedstawienie argumentów i dyskusja w celu przekonania drugiej strony ${ }^{17}$, to manipulacja posuwa się do używania kłamstw lub półprawdy.

Problem w tym, że wyborcy godzą się z tym, że są oszukiwani. W naszej rzeczywistości przywykliśmy już do tego, że wybory i polityka kojarzone są z kłamstwami i oszustwem, wobec czego nikt nie wymaga faktycznej realizacji złożonych obietnic. Jak zresztą pokazały przywoływane już wcześniej wyroki sądowe, obietnice składane przez polityków i partie w ramach kampanii wyborczej, nie są dla nich w żaden sposób zobowiązujące, co również sprzyja składaniu obietnic, które pozostają potem bez pokrycia.

Oczywistym jest, że nie istnieje prosta zależność, w myśl której samo złożenie danej obietnicy przekłada się na konkretną ilość głosów wyborców. Mimo to, zwykle można wykazać, że pewne deklaracje, na czele z programem wyborczym ${ }^{18}$, wpływają na decyzje wyborców.

Kolejnym aspektem wpływającym na mechanizmy obietnic jest krótka pamięć wyborców. Wielu z nich szybko po wyborach zapomina o tym, co zostało im obiecane, za wyjątkiem kilku wybranych obietnic, zwykle tych, które są najdłużej i najczęściej obecne w mediach. W przypadku pozostałych deklaracji, w ciagu kilku dni po wyborach większość wyborców nie jest w stanie przypomnieć sobie większości z nich, a co więcej, często nie są także w stanie rozróżnić kto jaką obietnicę złożył. Duży wpływ na to ma także fakt, że tylko nikła część społeczeństwa interesuje się programami wyborczymi partii.

\footnotetext{
16 Kobiety i mężczyźni na rynku pracy, www.stat.gov.pl/cps/rde/xbcr/gus/f_kobiety_i_mezczyzni_ na_rynku_pracy_2012.pdf, data dostępu 1.03.2013.

17 M. Pabijańska, Psychomanipulacja w polityce, Wrocław 2006, s. 15.

18 Program wyborczy rozumiany jako suma obietnic, a nie dokument programowy partii.
} 
Tutaj wracamy do poruszanych na początku kwestii etyki i uczciwości. Bardzo rzadko obietnice wyborcze dają się łatwo określić jako nierealne lub niemożliwe do zrealizowania, zwłaszcza w oczach przeciętnego wyborcy. Zwykle dopiero dokładniejsza analiza pozwala stwierdzić, że to co nam obiecuja politycy, jest zbyt optymistycznym założeniem, albo tylko „magnesem” na głosy. W wielu przypadkach wynika to ze zwykłego cynizmu i chęci osiagnięcia zwycięstwa wyborczego za wszelką cenę. Postępowanie takie możemy określić jednoznacznie jako nieetyczne i niepożądane, jednak egzekwowanie właściwego zachowania okazuje się zwykle ponad siły i możliwości wyborców, co jest wykorzystywane podczas każdej elekcji.

Nieetyczne jest także składanie obietnic, których nie mamy zamiaru realizować. Ten przypadek jest najbardziej godny potępienia, bowiem zachowanie obliczone jest tylko na przyciagnięcie wyborców, wzbudza w nich poczucie, że realizacja takiej, czy innej potrzeby jest możliwa do zrealizowania, a później (o ile dana obietnica zostanie zapamiętana) pozostawia ich z poczuciem zawodu.

Składanie obietnic jest nieodłącznym elementem każdych wyborów. Gdyby nie one, to nic innego, poza cechami charakteru i fizycznymi nie pozwalałoby odróżniać od siebie poszczególnych kandydatów lub ugrupowań. W momencie, gdy wyborcy oczekują na kolejne obietnice, politycy robią wszystko by nie zawieść tych oczekiwań i prześcigają się w kolejnych deklaracjach.

$Z$ drugiej strony wyborcy nie radzą sobie z egzekwowaniem realizacji tego, co im obiecano, co szkodzi przede wszystkim im samym, ale także demokracji jako takiej, bowiem prowadzi do obniżania standardów demokratycznych w naszym kraju. Politycy bez skrupułów wykorzystują mechanizmy rządzące decyzjami wyborców by przeciagnać ich głosy na swoją stronę.

Czasami obietnice składane są w dobrej intencji, lecz zbyt pochopnie lub w zbyt wielkim uproszczeniu, wywołując mylne oczekiwania wśród wyborców. Politycy chcacy realizować swój program, napotykaja także na różne przeszkody w postaci braku uprawnień, zmiany sytuacji politycznej i gospodarczej na świecie, umowy koalicyjne (i ich późniejsze renegocjacje) itp. W tej sytuacji należy stwierdzić, że najważniejsza jest kontrola wykonania deklaracji oraz pamięć wyborców 0 tym, co zostało im przyrzeczone. By obietnice składane były uczciwie i etycznie, społeczeństwo musi zacząć interesować się programami partii i nie pozwolić, by jego uwage odwracały wywoływane na poczekaniu afery o niskim znaczeniu społecznym. Dopóki sami nie zaczniemy walczyć o egzekwowanie obietnic wybor- 
czych, politycy wciąż będą nam obiecywać znacznie więcej niż są w stanie zagwarantować. 